\title{
Congress backs historic expansion of NSF
}

\section{Geoff Brumfiel, Washington}

In a major boost for the physical sciences in the United States, Congress has passed a bill that recommends doubling the budget of the National Science Foundation (NSF) over the next five years.

Passage of the NSF Authorization Act of 2002, which President Bush is expected to sign before the end of the year, is seen as a historic landmark for the science agency, which supports most non-biomedical research at US universities, in disciplines ranging from computer science to geology.

Scientific societies have been eagerly pursuing such a measure for years, to match the doubling since 1998 of the budget of the main biomedical research agency, the National Institutes of Health (NIH). But it remains to be seen whether Congress will enact the $15 \%$ increases in the NSF's budget for each of the next five years recommended by the bill.

"Symbolically, this says there's bipartisan support for the NSF," says Samuel Rankin, chair of Coalition for National Science Funding, an alliance of scientific societies that lobbies for NSF funding. Congressional appropriations committees, which actually allocate funds, have already decided to give the NSF a $12 \%$ increase for next year, bolstering the view that they are ready to support the agency's rapid expansion.

If the doubling does take place, disciplines that are likely to benefit include Earth sciences, mathematics, chemistry and computer science, which all rely heavily on the NSF for support. The agency also supports physics and biology, although the Department of Energy and the NIH, respectively, are far larger backers of these disciplines.

The doubling measure was welcomed by university physicists. "My hope is that this bill will allow the growth of new initiatives, while providing relief to ongoing programmes," says Barry Barish, a physicist at the California Institute of Technology in Pasadena and a newly elected member of the National Science Board, the NSF's governing body.

The bill was championed by Sherwood Boehlert (Republican, New York), chair of the House Science Committee. In a change from earlier versions of the legislation, the fourth and fifth years of increases are contingent on a congressional review of the NSF's management practices. This modification was one of several made in late negotiations with the White House Office of Management and Budget, which had previously opposed the bill on the grounds that five years was too long for a funding commitment.

The measure also directs the NSF to prioritize its large infrastructure projects. The agency currently has around half a dozen such projects awaiting funding, with no clear order in which they are to start. This situation is frustrating to project advocates in Congress, as well as researchers, says Rankin.

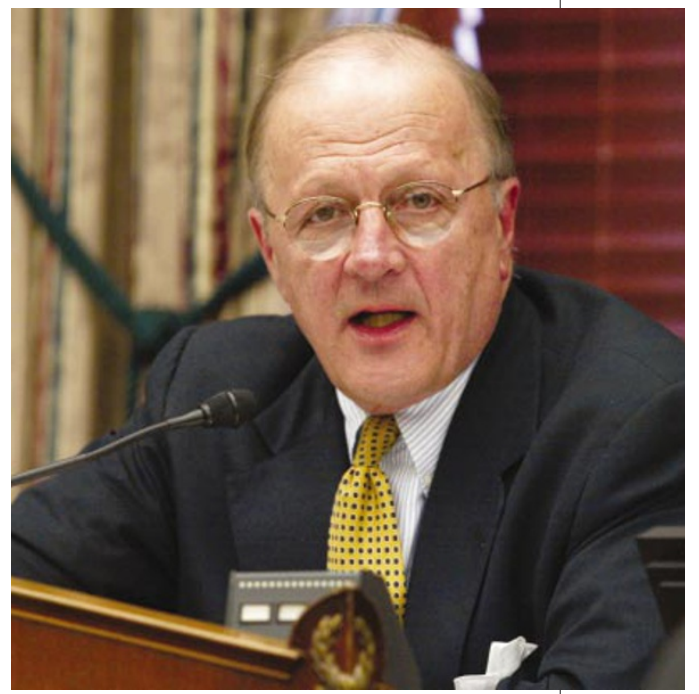

Sherwood Boehlert: champions funding hike.

Congress also passed a separate cybersecurity bill that recommends spending almost $\$ 1$ billion on computer security over five years, with half of the money going to the NSF. Gene Spafford, director of the Center for Education and Research in Information Assurance and Security at Purdue University in Indiana, says the cash would help research on the protection of advanced computer networks, and expand the number of doctorates issued in computer security.

\section{'Independent' biology institute targets China's exiles}

\section{David Cyranoski}

China is to step up its efforts to lure talented biologists back home through a new institute that, its supporters say, will offer them more money and much more autonomy than other laboratories there.

After several false starts, the planned National Institute of Biological Sciences, Beijing, has just named its governing board, and over the next few months aims to recruit a director, 28 principal investigators and an external advisory board .

Bureaucrats often call the shots at China's main existing research institutes, creating a rigid image that can undermine efforts to entice back some of the thousands of Chinese scientists working abroad. "The new institute will be established as an independent organization and will be mainly run by biological scientists," pledges Ray Wu, a biologist at Cornell University in Ithaca, New York, and an informal adviser to the Chinese government on the project.

Researchers' salaries at the institute will be set at about halfway between typical levels in the United States and in China outbidding the prestigious Chinese Academy of Sciences (CAS), which has already had some success in attracting prominent scientists back to China. Each primary investigator will be allocated enough laboratory space for a team of ten researchers, postdoctoral fellows and technicians in the institute's building at the Zhongguancun Life Science Park, about five miles north of Peking University. The building, designed for a separate biologicalsciences project, was taken over when those plans fell through.

The institute's investigators will mostly be recruited from abroad, says $\mathrm{Wu}$, to avoid accusations of poaching talent from elsewhere in China. "The new investigators will add strength to the existing scientific community in China," Wu adds.

The project will receive 400 million yuan renminbi (US\$50 million) from the city of Beijing for building and equipment, plus 300 million yuan from the Ministry of Science and Technology to cover running costs for five years. The institute will be devoted entirely to basic research, with its remit split between agricultural and health sciences.

"It will be able to recruit some of the best in the field," predicts Yongbiao Xue, associate director of the CAS's Institute of Genetics and Developmental Biology. "It could really push forward a lot of things in China."

Some researchers are sceptical about whether the institute will be able to maintain its promised level of autonomy, but many are optimistic. "The institute could set an example for research work in China," says Zhi-hong Xu, president of Peking University. "The system needs a lot of changes," he adds.

$\mathrm{Xu}$ and others are somewhat concerned, however, that insufficient provision has been made for interaction with other research institutions in China, and $\mathrm{Xu}$ suggests that the investigators should be required to hold joint positions with nearby universities. 